DOI: $10.15290 /$ bsl.2020.17.08

\author{
Agnieszka Możejko \\ Wydział Filologiczny \\ Uniwersytet Gdański \\ e-mail: mozejko2211@gmail.com \\ ORCID: 0000-0001-9239-9298
}

\title{
Warmińska idylla dla oka turysty. Poetyka popularnych przewodników i blogów
}

Przewodniki turystyczne przez długi czas stosunkowo rzadko stawały się przedmiotem badań literaturoznawczych na gruncie polskim. Badacze zainteresowali się poetyką tego gatunku pod koniec lat 70., szczególnie skupiając się na przewodnikach górskich, ze względu na wyjątkowe znaczenie tego regionu dla polskiej tożsamości ${ }^{1}$. Wraz z pojawieniem się $w$ humanistyce zwrotu topograficznego zainteresowanie tego typu utworami wzrosło ${ }^{2}$, lecz o literaturoznawcze teksty teoretyczne poświęcone przewodnikom po regionach o mniejszej rozpoznawalności i słabiej wyrobionej tożsamości lokalnej, do jakich należy Warmia, wciąż trudno.

Relacja między miejscem a tekstami na jego temat jest skomplikowana - z jednej strony literatura czy innego rodzaju artystyczne przedstawienia miejsca mogą je nobilitować, $\mathrm{z}$ drugiej odniesienie się $\mathrm{w}$ tekście do regionu, który już istnieje w wyobraźni odbiorców jako ważny i ciekawy, może pomóc w sukcesie dzieła. Niewątpliwie jednak medialne przedstawienia regionu współtworzą przestrzeń, którą opisują, poprzez konstruowanie lub utrwalanie wyobrażeń na jej temat - to zjawisko jest szeroko wykorzystywane przez

\footnotetext{
1 J. Żmidziński, Przewodnik jako scenariusz rytuałów turystycznych (na podstawie dawnych bedekerów pienińskich). Narodziny pewnej religii, „Napis” 2010, nr 16, s. 477.

2 E. Rybicka, Geopoetyka, geokrytyka, geokulturologia. Analiza porównawcza pojęć, „Białostockie Studia Literaturoznawcze" 2011, nr 2, s. 27-28.
} 
branżę turystyczną. Jak to ujęła Elżbieta Konończuk w artykule Geograficzne doświadczenie lektury:

Są miejsca, które swoją atrakcyjność turystyczną zawdzięczają ważnym wydarzeniom historycznym czy kulturalnym. Są także takie, które zawdzięczają ją artystycznym reprezentacjom, malarskim, filmowym, literackim. Reprezentacje te przyciągają odbiorców sztuki, wiedzionych z jednej strony potrzebą konfrontacji rzeczywistych miejsc z wyobrażeniem artystów oraz z własną konkretyzacją, z drugiej zaś potrzebą doświadczenia niezwykłej aury miejsca, które dzięki na przykład literaturze zajęło ważne miejsce w pamięci i wyobraźni zbiorowej ${ }^{3}$.

Teksty należące do dyskursu turystycznego stanowią pewnego rodzaju katalog najbardziej nośnych i współcześnie atrakcyjnych spośród powstałych przez lata wyobrażeń na temat danego miejsca. Turystyka czerpie $\mathrm{z}$ istniejących reprezentacji artystycznych, a promowane przez nią przedstawienia regionu z czasem wpływają na samą przestrzeń i wyobrażenia mieszkańców na jej temat. Ten mechanizm, wraz z jednym $z$ efektów jego działania, jakim jest nobilitacja miejsca $\mathrm{w}$ oczach mieszkańców, zwłaszcza nienawykłych do zainteresowania artystów, Konończuk opisała na przykładzie Podlasia, gdzie w ostatnich latach często lokowano akcję utworów literackich, co zdynamizowało jego obraz w zbiorowej wyobraźni, a mieszkańcom pozwoliło konkretyzować otaczające ich miejsca jako lepsze i ciekawsze niż $\mathrm{w}$ rzeczywistości ${ }^{4}$. Warto dodać, że szczególnie nośne przedstawienia literackie budzić mogą dążenia do uczynienia realnej przestrzeni bardziej podobną do tej znanej z dzieł, zwłaszcza jeżeli miałoby to ją uczynić atrakcyjniejszą turystycznie ${ }^{5}$.

Pojawienie się i popularność nowych mediów, takich jak telewizja i Internet, zmodyfikowało relacje społeczne i obniżyło znaczenie literatury jako medium kształtującego obrazy przestrzeni. Coraz większy wpływ na ludzi wywierają przekazy audiowizualne, a relacjonowanie podróży, zwłaszcza za pomocą zdjęć, wraz ze wzrostem popularności mediów społecznościowych stało się dużo bardziej powszechne. Dzięki Internetowi każdy może być autorem uczestniczącym w dyskursie publicznym i współtworzącym wyobrażenia na temat miejsc, które odwiedza. Treści formułowane i udostępniane przez blogerów i influencerów docierają do szerokiego grona odbiorców,

\footnotetext{
3 E. Konończuk, Geobiograficzne doświadczenie lektury, w: Przestrzenie geo(bio)graficzne w literaturze, red. E. Konończuk, E. Sidoruk, Białystok 2015, s. 67-68.

4 Tamże, s. 68-70.

5 Zjawisko recepcji literatury w przestrzeni wraz z jego aspektem promocyjnym szerzej opisała Magdalena Lachman w artykule Literackie aktywacje przestrzeni miejskich - nowa arteria komunikacyjna czy ślepy zaułek estetyki?, „Kultura i Historia” 2016, nr 30.
} 
a ich znaczenie jest coraz większe. Siła tego rodzaju przekazów bierze się $\mathrm{w}$ dużej mierze $\mathrm{z}$ wpisanego $\mathrm{w}$ nie potencjału identyfikacji czytelnika $\mathrm{z}$ autorem i zaufania, jakim go obdarzają. Świadczyć może o tym choćby skuteczność reklam szeptanych na blogach ${ }^{6}$.

Blogi podróżnicze stanowią odrębną niszę w świecie internetowych blogów. Jest to, obok blogów modowych, jedna z najpopularniejszych odmian tematycznych tego rodzaju wypowiedzi internetowych. Szerokie zainteresowanie tymi przekazami doprowadziło do powstania zawodowych blogerów-podróżników, utrzymujących się z multimedialnego relacjonowania swoich wyjazdów ${ }^{7}$. Pojawienie się tej profesji pokazuje, jak duże znaczenie we współczesnym świecie mają twórcy internetowi i jak istotna jest analiza ich tekstów dla zrekonstruowania obrazu danego regionu w zbiorowej wyobraźni.

Ze względu na to, że do języka turystyki zaliczyć można język reklam, przewodników, reportaży, pracowników branży turystycznej oraz samych turystów dzielących się wrażeniami z podróży, pojęcie to jest nieostre, a dokładna kategoryzacja typów języka turystycznego była wielokrotnie dyskutowana. W artykule tym omówione zostaną, przy wykorzystaniu klasyfikacji zaproponowanej przez Julię Murrmann, teksty dotyczące Warmii, adresowane do konsumenta usług turystycznych, operujące komercyjnym językiem prasy turystycznej oraz opisy wrażeń zamieszczane na blogach internetowych i w serwisach społecznościowych przez turystów, którzy odwiedzili ten region ${ }^{8}$.

Początkowym problemem, jaki pojawia się przy analizie tekstów na temat Warmii, jest jej częste przedstawianie wspólnie z Mazurami. Treści dotyczące "Warmii i Mazur" mogą się odnosić do obu tych regionów w nierównym stopniu, a przy ujednolicającym ujęciu trudno rozstrzygnąć ostatecznie, w jakiej mierze mowa o Warmii, a w jakiej o Mazurach. Ze względu na ogromną turystyczną popularność Mazur domniemywać można, że większość przynależących do dyskursu turystycznego tekstów o Warmii i Mazurach odnosi się przede wszystkim do tych drugich, jednak nie da się tego dokładnie ustalić. Można mówić natomiast o wspólnych motywach, jakie pojawiają się w wypowiedziach na temat Warmii i Mazur, mających charakter informacji dla turystów - jednym z nich jest przedstawienie rejonu jako miej-

\footnotetext{
6 M. Stachowiak, Rola blogów w podejmowaniu decyzji zakupowych dotyczących produktów odzieżowych, „Handel Wewnętrzny” 2017, nr 5.

7 Zob. B. Koturbasz, Multimedialne podróżopisarstwo, czyli narodziny travelebrity, „Panoptikum” 2009, nr 8; E. Rybicka, Geopoetyka, geokrytyka, geokulturologia. Analiza porównawcza pojęć.

8 J. Murrmann, Profesjolekt branży turystycznej, czyli o specyficznych cechach zawodowego języka turystyki, „Rozprawy Naukowe Akademii Wychowania Fizycznego we Wrocławiu” 2014, nr 47, s. 49.
} 
sca oddalonego od cywilizacji, zwykle w celu podkreślenia piękna lokalnej przyrody, na łonie której turysta będzie mógł podczas urlopu odpocząć od zanieczyszczonego powietrza i codziennego zgiełku miasta, aby zregenerować siły poprzez bliski kontakt $\mathrm{z}$ naturą.

Teksty skierowane do turystów przedstawiają Warmię przede wszystkim jako miejsce, w którym człowiek znajduje się bliżej natury. Status Warmii i Mazur jako krainy tysiąca jezior jest bardzo chętnie wykorzystywany przez marketingowców rekomendujących region jako przestrzeń doskonałą do wypoczynku, w której - to określenie pojawia się często w broszurach dla turystów - czas płynie wolniej. Jak czytamy w wydanym przez „Świat Książki" albumie Warmia i Mazury:

Północno-wschodnia część Polski - Warmia, Mazury i Suwalszczyzna - to malownicza kraina jezior, rzek, wzgórz i lasów, dająca oddech zapracowanej reszcie kraju. Jej wspaniałe, kojące krajobrazy stają się w każde wakacje celem odwiedzin coraz liczniejszej rzeszy turystów i letników ${ }^{9}$.

Warmia jawi się jako kraina wakacyjna, w której nie ma miejsca na pracę. Perspektywa, z jakiej zostaje opisany region, jest całkowicie zewnętrzna, a jego rola zawężona do znaczenia, jakie ma dla mieszkańców pozostałej części Polski.

Jezioro, najczęściej wymieniany w tekstach turystycznych element krajobrazu analizowanych przestrzeni, w tekście wstępnym Warmii i Mazur przedstawione jest jako nie tylko formacja przyrodnicza, ale też fenomen kulturowy: „W swojej różnorodności postaci i tajemniczości głębin niezmiennie fascynuje: tak miejscowych, którzy wiążą z nim rozmaite przekonania, anegdoty, legendy, jak i przyjezdnych, którzy znajdują na jego brzegach sposobność do uprawiania sportu, kąpieli, turystyki"10. W tekście zarysowany jest wyraźny podział na turystów i miejscowych, którzy, w odróżnieniu od tych pierwszych, wierzą $\mathrm{w}$ różne powiązane $\mathrm{z}$ naturą zjawiska, co może zostać uznane za kolejną atrakcję regionu, jego egzotyczny atrybut.

We właściwym wprowadzeniu do albumu na kolejnych stronach jako interesujący element regionu opisane zostają „materialne ślady obecności wielu mało znanych i egzotycznych dziś grup - od na wpół legendarnych Jaćwingów i Prusów po gromadkarzy i staroobrzędowców" ${ }^{11}$. Legendarne ludy wyznające nie do końca znane współcześnie kulty fascynują turystów, zwłaszcza

\footnotetext{
9 K. Kobus, A. Olej-Kobus, A. Dylewski, Warmia i Mazury, Warszawa 2007, s. 9.

10 Tamże, s. 7.

11 Tamże, s. 9.
} 
w kontraście z późniejszą historią biskupstwa warmińskiego. Warmia staje się miejscem, w którym kulty pogańskie spotykają się z chrześcijaństwem, co znajduje swój wyraz się $\mathrm{w}$ doborze zdjęć $\mathrm{z}$ Warmii $\mathrm{w}$ albumie - ujęcia zabytkowych kościołów przeplatają się $\mathrm{z}$ fotografiami bab pruskich.

Publikacja jest częścią serii, w której skład wchodzą również albumy przedstawiające fotografie innych regionów Polski. Z tyłu okładki znajduje się zbiorczy opis wydawnictw: „Wyjątkowa seria bogato ilustrowanych albumów, ukazujących zarówno miejsca bardzo znane, jak i czekające na odkrywców" ${ }^{12}$. O tym, że Warmia należy według tego przyporządkowania do miejsc jeszcze niezbadanych, świadczyć może jeden z opisów zdjęć: „Dolina Pasłęki na północnym skraju Warmii. Miejsce magiczne, a jednak ciągle jeszcze mało znane i rzadko odwiedzane" ${ }^{\prime 13}$.

Warmia określana jest jako „magiczna” nie tylko w tej publikacji. W 2007 roku nakładem wydawnictwa Bernardinum ukazał się album fotograficzny o tytule Magiczna kraina. Warmia i Mazury. Zebrane w nim zdjęcia przedstawiają głównie naturę, zabytkowe kościoły, przydrożne kapliczki i krzyże oraz groby. Jeśli pojawiają się na nich ludzie, to są to osoby łowiące ryby w jeziorach (w przedmowie określone jako „rybacy - cierpliwi łowcy"14) lub samotni mężczyźni w pustych domach (tytuł jednego z tych zdjęć brzmi $W$ starej chacie we wsi Naterki ${ }^{15}$ ), znajdziemy też fotografię człowieka obsługującego zaprzęgnięty w konia siewnik oraz mężczyzny prowadzącego wóz konny. Jedyne zdjęcie przedstawiające ludzi używających nowoczesnego sprzętu ukazuje dwie osoby jadące na motorze przez błotnistą drogę na tle zniszczonego drewnianego płotu.

Z fotografii wyłania się nostalgiczny, niewspółczesny obraz regionu, wpisujący się w zaobserwowaną i opisaną przez Małgorzatę Mikołajczak etnografizację, stanowiącą jeden z elementów dyskursu regionalistycznego ${ }^{16}$. Jest to miejsce bliskiego kontaktu człowieka z przyrodą, w którym ślady cywilizacji obróciły się w ruinę - na zdjęciach widzimy, cytując przedmowę, „ślady starych mieszkańców - opuszczone mury świątyń, malowidła, pochylone krzyże, kapliczki" ${ }^{17}$.

\footnotetext{
12 Tamże, tylna strona okładki.

13 Tamże, s. 16.

14 C. Dębowski, Magiczna kraina. Warmia i Mazury, Pelplin 2007, s. 7.

15 Tamże, s. 33.

16 Zob. M. Mikołajczak, Dyskurs regionalistyczny we współczesnym (polskim) literaturoznawstwie - pytania o status, poetyke i sposób istnienia, w: Nowy regionalizm w badaniach literackich. Badawczy rekonesans i zarys perspektyw, red. M. Mikołajczak, E. Rybicka, Kraków 2012, s. 29-50.

17 C. Dębowski, Magiczna kraina. Warmia i Mazury, s. 33.
} 
Przedstawianie Warmii i Mazur jako miejsca położonego poza cywilizacją nie jest nowością. W przewodniku Warmia i Mazury Jana Bałdowskiego z 1977 roku przeczytać możemy:

O atrakcyjności regionu zdecydowało wiele czynników, jak urozmaicony polodowcowy krajobraz, setki malowniczo położonych jezior, [...] coraz lepsze turystyczne zagospodarowanie oraz możliwość czynnego i biernego wypoczynku z dala od zgiełku i szumu przepełnionych ośrodków miejskich ${ }^{18}$.

W napisanym również przez Bałdowskiego przewodniku po województwie olsztyńskim z 1980 roku znajdziemy za to taki fragment: „Odwiedzający województwo turyści mają tu doskonałe warunki do czynnego lub biernego wypoczynku z dala od wielkomiejskiego szumu i zgiełku oraz nabrania sił do dalszej pracy"19. Już na tym przykładzie widać, że treść obu pozycji nie różni się wyraźnie.

U Bałdowskiego, tak jak w omawianych późniejszych tekstach, czytamy, że "Coraz więcej ludzi pracy i młodzieży szkolnej spędza tu swoje urlopy i wakacje" 20 . Trudno ocenić, na ile stanowi to odzwierciedlenie autentycznych statystyk, a na ile coś, co od lat przyjęło się pisać na temat Warmii i Mazur. Warto również zauważyć, że z przedstawionych tekstów wyłania się obraz Warmii i Mazur jako miejsca jednocześnie obleganego przez turystów i czekającego na odkrywców.

W przewodniku opublikowanym przez wydawnictwo Bosz w 2008 roku Warmia i Mazury po raz kolejny zostały przedstawione jako miejsce, którego zaletą z punktu widzenia turystów jest oddalenie od cywilizacji:

Warmia i Mazury to jeden z najsłabiej rozwiniętych gospodarczo regionów Polski. Być może jednak to jeden z powodów, dla których region ten jest tak atrakcyjny turystycznie. Nie ma tu dymiących kominów, wysokiej emisji spalin, hałasu, czyli zjawisk charakterystycznych dla obszarów wysoko rozwiniętych ${ }^{21}$.

W tej samej publikacji wraca również motyw piękna krajobrazu oraz, na drugim miejscu, zabytków jako najważniejszych zasobów regionu. Jak czytamy w pierwszych słowach przewodnika:

\footnotetext{
18 J. Bałdowski, Warmia i Mazury. Mały przewodnik, Warszawa 1977, s. 7.

19 J. Bałdowski, Województwo olsztyńskie, Inowrocław 1980, s. 3.

20 J. Bałdowski, Warmia i Mazury. Mały przewodnik, s. 7. Oba cytowane fragmenty zachowano $\mathrm{w}$ niezmienionej formie $\mathrm{w}$ wydaniu II poprawionym z 1982 roku, przetrwały one również $\mathrm{w}$ bardzo zbliżonej formie $\mathrm{w}$ kolejnej inkarnacji przewodnika wydanej pod tytułem Warmia, Mazury, Suwalszczyzna w 1997 roku.

21 S. Drej, J. Swajdo, Warmia i Mazury. Przewodnik, Olszanica 2008, s. 11.
} 
Oddajemy w ręce Czytelników przewodnik po regionie, którego najbardziej charakterystycznymi elementami są wspaniałe rzeki i jeziora oraz bogata fauna i flora. Nie można jednak zapominać, że jest to również obszar pełen zabytków, miejsc naznaczonych historią, ziemia pruskich grodzisk, krzyżackich zamków i gotyckich kościołów ${ }^{22}$.

W części przewodnika poświęconej mieszkańcom regionu autorzy zwracają uwagę na powstałą $\mathrm{w}$ wyniku przesiedleń mieszankę etniczną i kulturową oraz fakt, że na terenach Warmii i Mazur nie pozostali prawie żadni rdzenni mieszkańcy.

Na ten aspekt zwrócili uwagę również autorzy przewodnika wydawnictwa Demart z 2012 roku. Jak czytamy w części poświęconej etnografii Warmii i Mazur: „W 1945 r. Warmię włączono do państwa polskiego. Jej dotychczasowi mieszkańcy albo uciekli przed frontem wojennym, albo zostali wysiedleni. Dlatego też obecnie obszar ten zamieszkuje w większości ludność napływowa" ${ }^{23}$. Autorzy piszą też o zlewaniu się w jeden byt tożsamości Warmii i Mazur: "Na wschód od Żuław leży Warmia, obecnie często mylona z Mazurami. Jej własna tożsamość nieubłaganie zanika" ${ }^{24}$, prognozując całkowite kulturowe pochłonięcie jednego regionu przez drugi.

Zamieszczane w Internecie materiały na temat Warmii i Mazur wykazują podobne cechy co teksty drukowane, wpisując się w dyskurs turystyczny. Na stronie internetowej National Geographic znajdziemy serię stworzonych w porozumieniu z Serwisem Gospodarczym Warmii i Mazur artykułów o charakterze reklamowym na temat zalet inwestycji biznesowych na tych terenach, w których zaobserwować można podobny sposób opisywania regionu i jego atutów, co w przewodnikach i albumach.

W pierwszym $z$ artykułów ${ }^{25}$ napisano, że na Warmii i Mazurach znajdują się „wioski na przysłowiowym krańcu świata” czy też że w regionie można „zaszyć się w chatce w samym środku lasu”. Użycie obu zwrotów wskazuje na zastosowanie podobnego obrazowania - Warmia i Mazury to miejsce położone na rubieżach ludzkich siedlisk, zdominowane przez naturę i słabo zurbanizowane. Wykorzystywanie odniesień do świata baśni w branży turystycznej nie jest wyjątkowe dla Warmii i Mazur ${ }^{26}$, z pewnością jednak tego

\footnotetext{
22 Tamże, s. 7.

23 E. Lodzińska, W. Wieczorek, Warmia i Mazury, Warszawa 2012, s. 19.

24 Tamże.

25 http://www.national-geographic.pl/traveler/kierunki/cud-prawdziwy-czyli-warmia-imazury [dostęp 7.12.18].

26 Por. S. Owsianowska, Stereotypy w narracji turystycznej, „Turystyka Kulturowa” 2014, nr 3, s. 13-14; A. Wieczorkiewicz, Apetyt turysty. O doświadczaniu świata w podróży, Kraków 2008, s. 295-297.
} 
rodzaju nawiązania znajdują podatny grunt $\mathrm{w}$ tekstach na ich temat. Opis odsyłający do baśni pojawił się także w omówionym wcześniej albumie fotograficznym Magiczna kraina. Warmia i Mazury, gdzie czytamy: „Zatopione w porannej mgle jeziora przywodzą na myśl baśniowe krainy" 27. Zbiór odniesień, z którego korzystają autorzy piszący na temat Warmii i Mazur z myślą o osobach, które potencjalnie mogą je odwiedzić, w różnych typach tekstów pozostaje ten sam.

Pojawiający się $\mathrm{w}$ przewodnikach kontrast pomiędzy zapracowanym, cywilizowanym miastem a Warmią i Mazurami, miejscem na odpoczynek, widoczny jest i w omawianym artykule internetowym: "Zamiast zgiełku wielkiego miasta, pracownicy wielu warmińsko-mazurskich firm słyszą ciszę, mogą podziwiać gęste, rozległe lasy i piękne jeziora". W cytowanym fragmencie widoczna jest ponadto daleko posunięta homogenizacja Warmii i Mazur: nie napisano o firmach $\mathrm{z}$ województwa warmińsko-mazurskiego, ale o warmińsko-mazurskich firmach, co - jeżeli odrzucimy możliwość zaistnienia w tekście błędu językowego - oznacza firmy mieszczące się $\mathrm{w}$ obu regionach lub wywodzące się $\mathrm{z}$ jednego regionu warmińsko-mazurskiego.

Region został podobnie zaprezentowany w drugim artykule ${ }^{28}$, w którym przeczytać można, że sceneria miejsca jest magiczna, co ponownie budzi baśniowe skojarzenia. Bliski kontakt $\mathrm{z}$ naturą, jak to przedstawiono $\mathrm{w}$ tekście, daje przedsiębiorcom energię na kolejne wyzwania i dzięki niemu to właśnie na Warmii i Mazurach powstał projekt drukarki 3D. W trzecim tekście z serii czytamy: „na miejscu nie uświadczysz korków ani zanieczyszczeń, czyli zmory metropolii - tutaj żyje się wolniej, bliżej natury. Do pracy można dojeżdżać na rowerze, oddychając świeżym powietrzem zamiast spalinami samochodów. Albo po prostu pracować z ogrodu!" 29. Obraz wyłaniający się z tych tekstów przedstawia Warmię i Mazury jako biznesową utopię, alternatywę dla wielkich miast i miejsce dla ludzi kreatywnych, w którym oddalenie od cywilizacji wspomaga produktywność pracowników.

Taka wizja prowincji zgodna jest z rozpoznaniem Katarzyny Sawickiej-Mierzyńskiej, która w artykule Przemiany zakresu pojęć "prowincja” $i$ "centrum" w piśmiennictwie podlaskim przed i po 1989 roku opisała na przykładzie

\footnotetext{
27 C. Dębowski, Magiczna kraina. Warmia i Mazury, s. 23.

28 http://www.national-geographic.pl/national-geographic/1000-powodow-aby-odwiedzicwarmie-i-mazury [dostęp 7.12.18].

${ }^{29}$ http://www.national-geographic.pl/info/nowe-biuro-naturalnie-na-warmii-i-mazurach [dostęp 7.12.18].
} 
Podlasia dwa sposoby obrazowania prowincji: jako przestrzeni zaściankowej lub stymulującej kreatywność. W artykule czytamy:

Odwrotnością tej postawy jest traktowanie prowincji jako przestrzeni idealnej dla kreatywnego działania. Tytuł rozmowy Piotra Tomaszuka z Krzysztofem Rauem brzmi: Tu wszystko jest możliwe. Podobnie pisał w Linii powrotu Krzysztof Czyżewski (praktyk idei - jak sam siebie określa), dla którego przygraniczne Sejny stały się miejscem życiowego i artystycznego spełnienia ${ }^{30}$.

Jak dalej pisze badaczka, warto zauważyć, że wymienieni autorzy nie pochodzą z Podlasia. $W$ narracjach inregionalnych dominuje motyw zapóźnienia względem centrum i poczucie, że prowincjonalne pochodzenie zmniejsza życiowe szanse na karierę, sukces itp. ${ }^{31}$

Zalety Warmii i Mazur opisywane są w kontraście do innych, bardziej cywilizowanych miejsc, a jednocześnie często pojawiają się porównania do części Europy lub Polski o większej rozpoznawalności. Na blogach „Szalone walizki" 32 oraz "Gdzie wyjechać" ${ }^{33} \mathrm{w}$ postach poświęconych podróżom po Warmii i Mazurach autorzy nazywają zamek biskupów warmińskich w Lidzbarku Warmińskim Wawelem Północy ${ }^{34}$, a cały region porównują do Prowansji, w przypadku drugiego blogu - również do Toskanii. Jako że twórcy blogu „Gdzie wyjechać” zamieścili w swoim wpisie odsyłacz do starszego postu pochodzącego z blogu "Szalone walizki”, jest możliwe, że zastosowali wymienione porównania, bazując na własnym pomyśle, co nie znaczy, że nie należy traktować ich gestu jako świadectwa nośności tych skojarzeń. Jak czytamy we wpisie o tytule Odkrywamy sielankowa Polskę. Siedlisko Blanki i skarby zielonej Warmii na blogu "Gdzie wyjechać”:

Alejami starych platanów zachwycaliśmy się w Prowansji. W Toskanii charakterystycznym elementem krajobrazu są ciągnące się niczym wstęgi aleje cyprysów. Prezentują się niezwykle malowniczo z oddali, nadając łagodnym wzniesieniom

${ }^{30}$ K. Sawicka-Mierzyńska, Przemiany zakresu pojęć "prowincja" $i$ "centrum” w piśmiennictwie podlaskim przed i po 1989 roku, w: Nowy regionalizm w badaniach literackich..., s. 105.

31 Por. M. Czermińska, „Punkt widzenia” jako kategoria antropologiczna i narracyjna, „Teksty Drugie" 2003, nr 2-3, s. 11-27.

32 https://www.szalonewalizki.pl/warmia-nie-zawsze-swieta/ [dostęp 10.12.19]. Pisownia i interpunkcja cytatów z blogów za oryginałem.

33 https://gdziewyjechac.pl/54201/odkrywamy-sielankowa-polske-siedlisko-blanki-i-skarbyzielonej-warmii.html [dostęp 10.12.19].

34 Jest to określenie użytkowane szerzej, m.in. w przewodniku National Geographic Warmia, Mazury i Podlasie z 2007 roku, przewodniku wydawnictwa Demart Warmia i Mazury z 2012 roku oraz artykule Relaks w niewielkim mieście. Niedoceniana Warmia na stronie internetowej Wirtualna Polska, https://turystyka.wp.pl/relaks-w-niewielkim-miescie-niedoceniana-warmia-629765287 5044481a [dostęp 18.01.20]. 
charakteru. Na Warmii to głównie lipy, klony, topole i dęby tworzą korytarze na drogach którymi przemierzamy kolejne odcinki pomiędzy miasteczkami i wioskami. Gdy promienie słońca przedostaną się przez zieloną czapę liści, świetlne refleksy ukazują się naszym oczom, nadając zwykłej drodze magicznego charakteru.

Porównania mają nobilitować opisywany region przez zestawienie $\mathrm{z}$ powszechnie znanymi ze swojego piękna krainami. Polskie drzewa zostają przedstawione jako podobne do platanów i cyprysów, ponieważ same w sobie wydają się niezbyt interesujące.

Przymiotnik "magiczny” jest wyjątkowo często wykorzystywany w tekstach, które mają zachęcić turystów do odwiedzenia regionu mało zurbanizowanego lub miasta o wiekowej zabudowie. Z określeniem Warmii jako „magicznej” spotykamy się nie tylko na "Gdzie wyjechać”, ale również na innych blogach, takich jak „Taste away" 35 czy wspomnianym wcześniej blogu „Szalone walizki", na którym w poście pod tytułem Warmia nie zawsze świętamalownicza kraina ludzi z duszą czytamy: „Więc wpadajcie na Warmię i poznajcie magiczną krainę nie zawsze świętą. Bo tu przyjeżdża się by poobcować z przyrodą i znaleźć taką formę wyciszenia jakiej poszukujemy i potrzebujemy. I na pewno każdy znajdzie coś dla siebie".

Autorzy podważają mit Warmii jako świętej i osadzają region w kontekście wypoczynkowo-rekreacyjnym, zbliżając go do Mazur. We wstępie do postu znajduje się fragment: "[Warmia - dop. A.M.] Czasem traktowana jak uboższa kuzynka znanych i lubianych Mazur. Mocno niesłusznie bo to jedno z najpiękniejszych miejsc w Polsce". Przedstawienie Warmii jako równie atrakcyjnej turystycznie, co Mazury ma ją nobilitować. Ze współczesnej perspektywy wizja regionu jako przyciągającego turystów pięknem natury wzbudza bardziej pozytywne skojarzenia, niż jego obraz jako historycznie silnie związanego z Kościołem rzymskokatolickim.

Spośród omawianych blogów „Szalone walizki” to jedyny, na którym znaleźć można odniesienie do mitu świętej Warmii, pomimo częstego występowania na innych blogach opisów zabytkowych kapliczek, kościołów i sanktuariów. Jest to też jedyny blog, którego autorzy deklarują warmińskie pochodzenie (zamieszkują w Olsztynie), z czego można wyciągnąć wniosek, że poza granicami Warmii region nie jest rozpoznawany w tym kontekście.

Najczęściej powracający wizerunek Warmii to obraz idylli, sielskiego raju stworzonego po to, aby można było w nim odetchnąć od codziennej pracy, ulicznego hałasu i zgiełku kojarzonych z miastem:

35 https://www.tasteaway.pl/2016/04/24/magiczne-miejsca-w-polsce-kwasne-jablko/ [dostęp 10.12.19]. 
W takich miejscach można poczuć klimat Warmii, sielskiej i rajskiej krainy pachnącej ziołami.

[Warmia nie zawsze święta - malownicza kraina ludzi z dusza, "Szalone walizki"]

Warmia nie zawsze święta - co łączy te miejsca i ludzi? A to, że większość z nich pochodzi spoza Warmii i Mazur. Najczęściej to warszawiacy, którzy wykonali skok na głęboką wodę, bo życie na wsi wydawało się takie proste. Często okazało się, że nie jest ale wzięli się z życiem za bary i stworzyli miejsca magiczne.

[Warmia nie zawsze święta - malownicza kraina ludzi z dusza, "Szalone walizki"]

Małgosia wpadła posłuchać i okazało się, że od roku prowadzi miejsce, gdzie zabiegane mieszczuchy mogą znaleźć wyciszenie i kontakt z naturą.

[Śniadanie na Warmii - Leśniczówka Gaja, „Szalone walizki”"36]

Pomiędzy warmińskimi miasteczkami i wsiami, gdzie dominują charakterystyczne gotyckie, ceglane kościoły, rozłożyło się sporo gospodarstw rolniczych ale i nowoczesnych agroturystyk, ekologicznych siedlisk, w których lubują się zmęczeni życiem i codzienną pogonią mieszkańcy miast.

[Odkrywamy sielankowq Polskę. Siedlisko Blanki i skarby zielonej Warmii, „Gdzie wyjechać"]

Warmię odwiedziliśmy w dzieciństwie. A dokładnie Frombork. Ale to tyle. Tym razem mieliśmy okazję zobaczyć ją od tej podobno typowej dla niej strony. Zielonej, idyllicznej, niespiesznej.

[Odkrywamy sielankowa Polskę. Siedlisko Blanki i skarby zielonej Warmii, „Gdzie wyjechać"]

Potem były jeszcze Klewki, gdzie Andrzej Lepper widział śmigłowiec lądujący z Talibami. Po nich już tylko sielskie, zielone krajobrazy pełne lekkich pofałdowań, spokojne, urocze, zapraszające nowo przybyłych podróżnych. I tak dojechałem do Olsztyna, stolicy Warmii, gdzie postanowiliśmy nie zrobić nic innego, a tylko i po prostu, dobrze się zabawić. Wraz z Magdaleną i przyjaciółmi wybraliśmy hotel nad jeziorem, na uboczu, z dala od centrum miasta.

[Olsztyn. Letni weekend na Warmii, „Wojażer" ${ }^{37}$ ]

Kwaśne Jabłko jest idealnym wyborem, jeśli macie ochotę na ucieczkę przed światem (w okolicy nie ma nic, tylko łąki i lasy!), ale też jeśli lubicie ładne miejsca $\mathrm{z}$ fajnym designem.

[Magiczne miejsca w Polsce: Kwaśne Jabłko, „Taste away”]

Blogerzy, zwykle pochodzący z miast, często opisują swoje wizyty w gospodarstwach agroturystycznych lub siedliskach prowadzonych przez szukających ucieczki od miasta właścicieli. Kontakt z innymi mieszkańcami Warmii jest odnotowywany rzadko, opis takiego spotkania znajdziemy jednak

36 https://www.szalonewalizki.pl/sniadanie-na-warmii-lesniczowka-gaja/ [dostęp 10.12.19].

37 https://wesolowski.co/2016/07/12/olsztyn-weekend-warmia/ [dostęp 10.12.19]. 
na blogu „Wojażer”: „Tuż obok terminalu czekała kolejka a obok niej sympatyczny mieszkaniec Warmii z papieroskiem w ręku i pęczkiem historii gotowych do opowiedzenia $\mathrm{w}$ pociągu, który $\mathrm{w}$ niecałą godzinę przewozi przyjezdnych z Szyman do Olsztyna". Opisany mężczyzna reprezentuje to, czego poszukują blogerzy przybywający na Warmię - nigdzie się nie spieszy, spokojnie pali papierosa i zawsze znajdzie czas, aby ubarwić pobyt turystów swoją opowieścią.

Miejscowa ludność zostaje też wspomniana w marginalnej uwadze w poście o tytule Śniadanie na Warmii - Leśniczówka Gaja na blogu "Szalone walizki”: „Na trasie Olsztyn-Szczytno pociągi na szczęście dla nas to rzadkość :), miejscowi już tak się nie cieszą". Niedogodności codziennego życia autochtonów stają się atutem dla turystów szukających miejsc, do których cywilizacja nie dotarła. Przedstawienie mieszkańców regionu jako elementu krajobrazu dostarczającego rozrywki turystom jest często spotykanym motywem relacji podróżniczych, o czym pisała między innymi Anna Wieczorkiewicz ${ }^{38}$. Takie ich ujęcie powraca $\mathrm{w}$ wielu tekstach dotyczących Warmii, również w przywoływanych wyżej albumach.

Na większości blogów temat Warmii pojawia się jednorazowo, zwykle opisany zostaje wyjazd na jeden weekend lub jedną wycieczkę, czasem region jest jedynie wspomniany ${ }^{39}$ lub poświęcony jest mu post wpisujący się w dłuższy cyk ${ }^{40}$. Wyjątek stanowi blog "Szalone walizki”, na którym Warmii dotyczy około dwudziestu postów ${ }^{41}$. Na blogu prowadzonym przez olsztynian deklarujących miłość do Warmii i Mazur, poza opisami dzikiej przyrody, ciszy i spokoju na łonie natury oraz powolnego rytmu życia, znaleźć można ujęcia Warmii zupełnie lub prawie zupełnie nieobecne na pozostałych omówionych blogach internetowych.

W poście Warmia - chillout pod gwiazdami ${ }^{42}$ region zostaje przedstawiony jako polska stolica astronomii. Autorzy odwołują się do postaci Mikołaja Kopernika oraz wyliczają planetaria i obserwatoria znajdujące się na Warmii, ale też na Mazurach. Autorzy zwracają uwagę na zakrojone na międzynarodową skalę projekty naukowe realizowane na Warmii oraz sukcesy, jakie w tej dziedzinie odnosi Uniwersytet Warmińsko-Mazurski:

\footnotetext{
38 A. Wieczorkiewicz, Apetyt turysty, s. 244-245, 313-314.

39 https://www.banita.travel.pl/gdzie-na-majowke-dlugi-weekend-w-polsce/ [dostęp 10.12. 19].

40 https://www.busemprzezswiat.pl/2017/08/warminsko-mazurskie-10-miejsc-ktore-musiszodwiedzic/ [dostęp 10.12.19].

41 Stan na 2019 rok.

42 https://www.szalonewalizki.pl/warmia-chillout-gwiazdami/ [dostęp 10.12.19].
} 


\begin{abstract}
Absolutnym hitem Warmii są placówki naukowe. Pod Olsztynem, w Bałdach, na terenie Uniwersytetu Warmińsko-Mazurskiego w 2015 roku powstała stacja LOFAR PL-612. To pierwsza $\mathrm{z}$ trzech planowanych stacji w Polsce. LOFAR to gigantyczny radioteleskop zbudowany na bazie licznych stacji w całej Europie. W jej skład wchodzi ponad 100 tysiącach punktów odbierających sygnały radiowe z kosmosu. Pozwala on oglądać gwiazdy odległe od Ziemi nawet o $7 \mathrm{mi}-$ liardów lat świetlnych. Szefem polskiego projektu jest profesor Andrzej Krankowski - wychowanek kortowskiej uczelni. [...] Uniwersytet Warmińsko-Mazurski pozytywnie zaskakuje. Radioteleskop w Bałdach to nie jedyne czym mogą się pochwalić naukowcy z Kortowa. W Lamkówku koło Barczewa od lat działa Obserwatorium Satelitarne, które służy głównie współpracy i badaniom opartym o amerykański system geolokacji. GPS zna każdy przeciętny Kowalski bo wbudowany $\mathrm{w}$ telefon czy nawigację pomaga nam wyznaczyć naszą pozycję i dotrzeć do celu.
\end{abstract}

We wpisie znajdziemy jednak również motywy typowe dla opisu Warmii $\mathrm{w}$ tekstach o tematyce turystycznej. Jak czytamy:

To najmniej zaludniony region w Polsce, $\mathrm{w}$ związku z tym najmniej oświetlony a dla obserwacji nieba to tylko zaleta. Poza tym na Warmii jest po prostu pięknie. Chociaż na promocję regionu poszły grube miliony i wydaje nam się, że wszystko wiemy, to Warmia jest wciąż mało odkryta.

Dyskurs turystyczny bywa również wykorzystywany w literaturze, czego interesujący przykład znaleźć można w powieści kryminalnej Gniew Zygmunta Miłoszewskiego. Postawa głównego bohatera, Teodora Szackiego, po przeprowadzce do Olsztyna początkowo wpisywała się w schemat zmęczonego życiem w mieście uciekiniera szukającego wytchnienia na Warmii i Mazurach. Bohater wprost stwierdza, że chociaż nie był wcześniej w Olsztynie, miał na jego temat konkretne wyobrażenia:

I gdzieś przy Olsztynie zdecydowało takie ukłucie, że to Mazury. Jeziora, lasy, słońce. Wakacje. W życiu tam nie był, zawsze jeździł nad morze, ale tak to sobie wyobrażał. Że się osadzi, znajdzie mały domek z widokiem na sosnowy zagajnik i będzie szczęśliwy, czytając wieczorami pogodne książki i dorzucając drewna do kozy ${ }^{43}$.

Z czasem jednak, po upływie dwóch lat, okazało się, że wyobrażenia Szackiego nie pokrywały się z rzeczywistością. Za moment zmiany stosunku bohatera do Warmii i Mazur - ze schematycznego odtwarzania narracji

43 Z. Miłoszewski, Gniew, Warszawa 2014, s. 62. 
rodem z dyskursu turystycznego do indywidualnej relacji z miejscem - uznać można chwilę, gdy przestaje on nazywać region, w którym leży Olsztyn, Mazurami, a zaczyna określać go jako Warmię, dając tym samym wyraz większej wiedzy na temat regionu.

Następnie postawa rozczarowanego Szackiego zostaje wielokrotnie skonfrontowana $\mathrm{z}$ punktem widzenia miejscowych patriotów - powracającym motywem w powieści staje się zachwyt olsztynian mieszkaniem w mieście, w granicach którego znajduje się jedenaście jezior, na co główny bohater każdorazowo reaguje w zgryźliwy i prześmiewczy sposób:

- Coraz więcej ludzi ściąga do nas, na Warmię - ciągnął niezrażony Bierut. I wcale się nie dziwię. Wie pan, że w Olsztynie tylko w granicach miasta jest jedenaście jezior?

- Dlatego reumatyzm zabija tu częściej niż choroba wieńcowa. Idziemy ${ }^{44}$.

Szarejna jak wszyscy tutaj była psychopatyczną lokalną patriotką, prędzej się ze smutku utopi $\mathrm{w}$ jednym $\mathrm{z}$ jedenastu olsztyńskich jezior, niż wyjedzie do Białegostoku albo Gdańska ${ }^{45}$.

- Rozumiem, Igorze, że jesteś tu przez chwilę, ale to wyjątkowe miejsce. Wiesz, że tylko w granicach miasta jest tutaj jedenaście jezior? Jedenaście!

Poniewasz spojrzał na nią uprzejmie.

- Naprawdę uważasz, droga Ewo, że to świadczy o wielkomiejskości tego miejsca? Ilość jezior, bagien i nieprzebytych lasów?

Szarejna zmartwiała, jakby ją uderzył, natomiast zdaniem Szackiego żart był pierwsza klasa ${ }^{46}$.

W przedstawionych fragmentach widzimy ironiczną odpowiedź na obraz miejsca promowany przez branżę turystyczną oraz sposób postrzegania Olsztyna przez mieszkańców, którzy chętnie wpisują opowieść o własnym mieście w nobilitujące je narracje zaczerpnięte $\mathrm{z}$ mediów. Uwaga na temat coraz większego zainteresowania przybyszy z zewnątrz Warmią jest prawie dosłownym cytatem z przewodnika Bałdowskiego, podkreślanie wyjątkowości miejsca poprzez zaznaczanie jego bliższego kontaktu z naturą w porównaniu do regionów silniej zurbanizowanych również stanowi echo wielu tekstów przywołanych do tej pory - takie podejście do regionu zostaje na kartach powieści skompromitowane.

\footnotetext{
44 Tamże, s. 110.

45 Tamże, s. 128.

46 Tamże, s. 133.
} 
Szczególnej uwagi warta jest zawarta w ostatnim cytacie wzmianka o wielkomiejskości stolicy Warmii. Olsztyn w oczach patriotów lokalnych na tle innych polskich miast wyróżnia się tym, że łatwiej w nim o kontakt $\mathrm{z}$ naturą, a więc mniej wielkomiejskim charakterem, a jednocześnie miasto pretenduje do wielkomiejskości. Gdy pochodzący z Warszawy prokurator Szacki naśmiewa się z tego paradoksu, kpi tym samym z kompleksów mieszkańców prowincji.

Wyraźne rozróżnienie między cywilizowanymi miastami a sielskimi Warmią i Mazurami wpisuje się w oparty na opozycjach model opisu kolonialnego, zaobserwowany przez Edwarda Saida ${ }^{47}$. Opisy mieszkańców jako części krajobrazu budującej koloryt miejsca oraz dostarczającej rozrywki turystom również łączą dyskurs turystyczny na temat Warmii i Mazur z dyskursem dotyczącym dawnych kolonii. Branża turystyczna dysponuje stałym sztafażem odniesień służących przedstawieniu opisywanego miejsca jako maksymalnie różniącego się od świata, który zna turysta, przy jednoczesnej sugestii, że wszystko w tym miejscu istnieje po to, by zadowalać potrzeby odwiedzających. Tego rodzaju narracja pojawia się w tekstach na temat państw pozaeuropejskich ${ }^{48}$, ale daje się zaobserwować również $\mathrm{w}$ opowieściach dotyczących poszczególnych regionów Europy.

Najłatwiej dostępne dla turystów materiały na temat Warmii rzadko wyłamują się poza zbiór stereotypów na temat rejonu powstały w dużej mierze z połączenia popularnego w dyskursie turystycznym obrazu Mazur z szeroko rozpowszechnionymi wyobrażeniami na temat regionów wiejskich i ich mieszkańców. Istnieją oczywiście publikacje pokazujące Warmię jako miejsce o odrębnym charakterze i historii ${ }^{49}$, lecz do popularnego obiegu elementy kultury warmińskiej trafiają poddane etnografizacji i egzotyzacji.

Teksty reklamowe nie są narzędziem edukacji. Często odwołują się do łatwo zrozumiałych i atrakcyjnych, ale nieskomplikowanych i nierzadko przynajmniej po części nieprawdziwych, obrazów już znanych czytelnikom. Jednak niezależnie od zgodności tego rodzaju tekstów ze stanem faktycznym, mają one realny wpływ na kształtowanie wizerunku regionów i są nieustannie powielane zarówno przez przybyszy z zewnątrz, jak i mieszkańców opisywanych terenów, dlatego warto zachować w stosunku do nich postawę krytyczną.

\footnotetext{
47 E. Said, Orientalizm, przeł. M. Wyrwas-Wiśniewska, Poznań 2018.

48 Por. N. Bloch, Oglądajacy i ogladani - czyli postkolonializm potrzebny turystyce, https://postturysta.pl/artykul/ogladajacy-ogladani [dostęp 19.01.20].

49 Zob. np. E. Cyfus, Moja Warmia, Dąbrówno 2012; E. Cyfus, I. Lewandowska, Magiczne wsie południowej Warmii. Przewodnik historyczno-kulturowy, Piwniczna Zdrój 2018.
} 


\section{Bibliografia}

Bałdowski Jan (1977), Warmia i Mazury. Mały przewodnik, Warszawa: Sport i Turystyka. Bałdowski Jan (1980), Województwo olsztyńskie, Inowrocław: Krajowa Agencja Wydawnicza.

Cyfus Edward (2012), Moja Warmia, Dąbrówno: Oficyna Wydawnicza Retman.

Cyfus Edward, Lewandowska Izabela (2018), Magiczne wsie południowej Warmii. Przewodnik historyczno-kulturowy, Piwniczna Zdrój: Agencja Wydawnicza WiT.

Czermińska Małgorzata (2003), „Punkt widzenia” jako kategoria antropologiczna i narracyjna, „Teksty Drugie”, nr 2-3, s. 11-27.

Dębowski Cezary (2007), Magiczna kraina. Warmia i Mazury, Pelplin: Bernardinum.

Drej Szymon, Swajdo Jarosław (2008), Warmia i Mazury. Przewodnik, Olszanica: Bosz.

Kobus Krzysztof, Olej-Kobus Anna, Dylewski Adam (2007), Warmia i Mazury, Warszawa: Świat Książki.

Konończuk Elżbieta (2015), Geobiograficzne doświadczenie lektury, w: Przestrzenie geo(bio)graficzne w literaturze, red. E. Konończuk, E. Sidoruk, Białystok: Wydawnictwo Uniwersytetu w Białymstoku.

Koturbasz Barbara (2009), Multimedialne podróżopisarstwo, czyli narodziny travelebrity, „Panoptikum”, nr 8, s. 117-124.

Lachman Magdalena (2016), Literackie aktywacje przestrzeni miejskich - nowa arteria komunikacyjna czy ślepy zaułek estetyki?, „Kultura i Historia”, nr 30, s. 24-35.

Lodzińska Ewa, Wieczorek Waldemar (2012), Warmia i Mazury, Warszawa: Demart.

Mikołajczak Małgorzata (2012), Dyskurs regionalistyczny we wspótczesnym (polskim) literaturoznawstwie - pytania o status, poetykę i sposób istnienia, w: Nowy regionalizm $w$ badaniach literackich. Badawczy rekonesans i zarys perspektyw, red. M. Mikołajczak, E. Rybicka, Kraków: Universitas, s. 29-50.

Miłoszewski Zygmunt (2014), Gniew, Warszawa: W.A.B.

Murrmann Julia (2014), Profesjolekt branży turystycznej, czyli o specyficznych cechach zawodowego języka turystyki, „Rozprawy Naukowe Akademii Wychowania Fizycznego we Wrocławiu", nr 47, s. 23-33.

Owsianowska Sabina (2014), Stereotypy w narracji turystycznej, „Turystyka Kulturowa”, nr 3, s. 6-20.

Rybicka Elżbieta (2011), Geopoetyka, geokrytyka, geokulturologia. Analiza porównawcza pojęć, „Białostockie Studia Literaturoznawcze”, nr 2, s. 27-39.

Said Edward (2018), Orientalizm, przeł. M. Wyrwas-Wiśniewska, Poznań: Zysk i S-ka.

Sawicka-Mierzyńska Katarzyna (2012), Przemiany zakresu pojęć "prowincja" i "centrum” w piśmiennictwie podlaskim przed i po 1989 roku, w: Nowy regionalizm w badaniach literackich. Badawczy rekonesans i zarys perspektyw, red. M. Mikołajczak, E. Rybicka, Kraków: Universitas.

Stachowiak Magda (2017), Rola blogów w podejmowaniu decyzji zakupowych dotyczacych produktów odzieżowych, „Handel Wewnętrzny”, nr 5, s. 336-346.

Wieczorkiewicz Anna (2008), Apetyt turysty. O doświadczaniu świata w podróży, Kraków: Universitas. 
Żmidziński Jakub (2010), Przewodnik jako scenariusz rytuałów turystycznych (na podstawie dawnych bedekerów pienińskich). Narodziny pewnej religii, „Napis”, nr 16, s. $477-493$.

\title{
Źródła internetowe
}

http://www.national-geographic.pl/traveler/kierunki/cud-prawdziwy-czyli-warmiai-mazury [dostęp 7.12.18].

http://www.national-geographic.pl/national-geographic/1000-powodow-aby-odwie dzic-warmie-i-mazury [dostęp 7.12.18].

http://www.national-geographic.pl/info/nowe-biuro-naturalnie-na-warmii-i-mazu rach [dostęp: 7.12.18].

https://www.szalonewalizki.pl/warmia-nie-zawsze-swieta/ [dostęp 10.12.19].

https://gdziewyjechac.pl/54201/odkrywamy-sielankowa-polske-siedlisko-blanki-iskarby-zielonej-warmii.html [dostęp 10.12.19].

https:// turystyka.wp.pl/relaks-w-niewielkim-miescie-niedoceniana-warmia-629765 2875044481a [dostęp 18.01.20].

https://www.tasteaway.pl/2016/04/24/magiczne-miejsca-w-polsce-kwasne-jablko/ [dostęp 10.12.19].

https://www.szalonewalizki.pl/sniadanie-na-warmii-lesniczowka-gaja/ [dostęp 10.12.19].

https://wesolowski.co/2016/07/12/olsztyn-weekend-warmia/ [dostęp 10.12.19]. https://www.banita.travel.pl/gdzie-na-majowke-dlugi-weekend-w-polsce/

[dostęp 10.12.19].

https://www.busemprzezswiat.pl/2017/08/warminsko-mazurskie-10-miejsc-ktoremusisz-odwiedzic/ [dostęp 10.12.19].

https://www.szalonewalizki.pl/warmia-chillout-gwiazdami/ [dostęp 10.12.19]. https://post-turysta.pl/artykul/ogladajacy-ogladani [dostęp 19.01.20].

\section{The Idyll of Warmia Seen with a Tourist's Eye: The Poetics of Popular Guide Books and Blogs}

\begin{abstract}
The article offers a comparative analysis of the selected fragments of tourist guides, photographical albums, advertisements and travel blogs about Warmia. The author points out how the language of commercial offers intersects with the accounts of tourist bloggers. The texts present Warmia as a secluded idyll, away from the hectic urban life, where people live in peace with nature.
\end{abstract}

Keywords: tourism, nature, guide books, blogs, language of advertising 